\title{
Embedding trade liberalisation in social policy: a research agenda on social regionalism and the Global South \\ DIAMOND ASHIAGBOR ${ }^{1}$
}

SOAS, University of London

\begin{abstract}
Underpinning this article is the proposition that regional integration with a social dimension has the potential to engender a more equitable pattern of globalisation. The empirical focus of the article is on the extent to which the insights of 'embedded liberalism' associated with regional economic integration between the industrialised nations of the European Union (EU) can be applied to regional economic integration within sub-Saharan Africa. The article contends that EU market liberalisation has been embedded within labour market institutions and institutions of social citizenship at the domestic level. These have served as social stabilisers to counter the far-reaching effects of the internal market and global trade. Less industrialised nations have never enjoyed adjustment mechanisms of this sort, raising the question for this article, and for further research: in which legal and institutional structures can these nascent forms of market integration at regional and sub-regional level be embedded?
\end{abstract}

\section{Introduction}

7 his article is part of a wider research project which interrogates the social dimension 1 of regional economic integration, by which is understood cooperation between states, principally in the area of trade policy, through common institutions and common rules. At the core is the question of the extent to which markets in general and trade liberalisation in particular may be embedded within, constituted by and ameliorated through the 'social' - in particular by labour law and social policy. Its central thesis is that regional integration with a social dimension has the potential to engender a more equitable pattern of globalisation - that 'social regionalism' can constructively counter more neoliberal versions of trade liberalisation.

In examining the interaction between trade liberalisation and labour standards, I draw on the work of Karl Polanyi. Central to his key work, The Great Transformation, is the assertion that all economies are enmeshed in non-economic institutions, although the forms and depth of this social embedding may differ. ${ }^{2}$ Drawing on Polanyi, I argue that

1 A version of this paper was presented at the workshop on 'Towards an Economic Sociology of Law' held at SOAS, University of London, in September 2012. I would like to thank my workshop co-organisers, Prabha Kotiswaran and Amanda Perry-Kessaris for their support and collaboration in bringing this project to fruition, and all the workshop participants for their stimulating comments.

2 Karl Polanyi, The Great Transformation: The Political and Economic Origins of Our Time (Beacon Press 2001 [1944]). 
laissez-faire economic liberalism may be offset by principles of social protection at national and, in some instances, regional level - a 'counter-movement' to the economic insecurity arising from globalisation. Through a case study of the EU, I contend that the 'embedded liberal compromise' of this regional integration project was predicated on the ability of these industrialised nations to embed the market within national institutions of social citizenship - principally labour and social welfare law.

Two key questions for this project are: first, is 'embeddedness' still a useful lens through which to understand the relationship between markets and society; and, second, what relevance does the concept of embeddedness have outside the Organisation for Economic Co-operation and Development (OECD) world? Given that the embedded liberal compromise was premised on the political and economic autonomy of individual industrialised states to regulate their territorially bounded markets, and of the regions they formed to enact something similar on a grander scale - what could be called 'social regionalism' - what scope is there for a similar intervention or social regionalism within sub-Saharan Africa? Developing states often lack the policy space, institutional or economic capacity to moderate the harmful domestic effects of market exposure. In addition, their economies are characterised by high levels of informalisation, in labour and other markets. ${ }^{3}$ It is highly problematic to expect individual states within, for example, sub-Saharan Africa to be the only, or main, source of their own (social) adjustment. ${ }^{4}$

My objective in this project is, therefore, to map ways in which trade liberalisation has been embedded within one example of regional economic integration (the EU) in order to chart an agenda for research which examines the wider significance of Polanyis analysis - at a different historical time, with reference to the South rather than the North, and against the backdrop of a changed global economic order. More specifically, I want to investigate the ameliorative potential of regional integration and regional collective action by developing states; what scope is there for social regionalism to embed waves of trade liberalisation between states that are industrialising as they integrate into world markets? But I am alert to the reflection that the evolution in the protective capacities of individual states of the North during the twentieth century and, later, the evolution in the protective capacities of the region, as seen in the context of European regional integration, took place against an ideological backdrop favourable towards embedded liberalism. In other words, the belief that governments (and then regions) should intervene to protect their populations 'from economic instability and insecurity', 5 in contrast to the current era of what might be called resurgent neoliberalism, or what Stephen Gill refers to as 'disciplinary neoliberalism' or 'neoliberal market civilisation', 6 characterised as it is by an emphasis on privatisation, deregulation and competitiveness.

To do this, I have been exploring the nature and value of an economic sociology of law; that is, the use of sociological approaches (empirical, normative, analytical) to investigate relationships between (labour) law and economy.

3 James Heintz and Robert Pollin, Informalization, Economic Growth and the Challenge of Creating Viable Labor Standards in Developing Countries Working Paper Series 60 (Political Economy Research Institute June 2003).

4 Adelle Blackett, Trade Liberalization, Labour Law, and Development: A Contextualization Discussion Paper Series 2007 (ILO, International Institute for Labour Studies 2007).

5 Andrew Lang, World Trade Law after Neoliberalism: Re-imagining the Global Economic Order (Oxford University Press 2011).

6 Stephen Gill, ‘Globalisation, Market Civilisation, and Disciplinary Neoliberalism’ (1995) 24 Millennium Journal of International Studies 399-423. 


\section{Embedding markets in social law}

In my attempt to understand the relationship between social rights and markets and the role for social rights in the operation of markets, I have gone back to, but perhaps now need to go beyond, Polanyi's concept of embeddedness.

Open markets create challenges for states and for society. Polanyi's insight was that, as the market system expands with regard to genuine commodities, it needs to be circumscribed in respect of fictitious ones, namely labour power and land (the environment). ${ }^{7}$ In other words, the pursuit of the myth or 'utopia' of a self-regulating market by means of laissez-faire economic liberalism and free trade will have a destructive impact on the 'human and natural substance' of society ${ }^{8}$ unless this expansion is met by a 'counter-movement', checking the growth of the market in order to protect society. What Polanyi refers to as the counter-movement relates to a political, regulatory response to markets: the forces of laissez-faire economic liberalism are offset by principles of social protection, as examples of which he includes trade union and anti-trust legislation, as well as legislation relating to public health, factory conditions, workmen's compensation, municipal trading, social insurance, public utilities and trade associations. ${ }^{9}$ Noteworthy here is the assertion of the importance of state action and social relations, not only in terms of the counter-movement, but also as constitutive of markets and essential for 'productive organization'. By this, one is led to understand, Polanyi meant that markets were anchored within institutional regulation. ${ }^{10}$ Hence statements such as '[l]aissez-faire was planned' and '[e]ven free trade and competition required intervention to be workable'. 11

Teasing out the primary intuition that economies are enmeshed or embedded within non-economic institutions, one can identify at least two meanings of 'embeddedness' in Polanyi's thought, with a third discernible from within a more recent Granovetter-inspired economic sociology. First, that all economies and economic behaviour are embedded to the extent that markets are constructed rather than being natural: 'The road to the free market was opened and kept open by an enormous increase in continuous, centrally organized and controlled interventionism'. ${ }^{12}$ But, second, is the idea that embeddedness differs from one economic system to another: that whilst it is not possible to fully disembed the economy from the rest of society, there are differences in the degree of enmeshment. ${ }^{13}$ My view is that these two meanings of embeddedness are reconcilable: if one rejects the orthodox account of the rise of the self-regulating market as a utopian project, it is difficult to conceive of markets as entirely disembedded.

I think this primary intuition about embeddedness is a helpful one. But I am aware of the difficulties with this approach to the relationship between market and society: primarily, the criticism made by Viviana Zelizer and others of the Polanyian distinction

7 Polanyi (n 2) 79-80.

8 Ibid 3.

9 Ibid 138-39, 153-57.

10 Jens Beckert, The Great Transformation of Embeddedness: Karl Polanyi and the New Economic Sociology MPIfG Discussion Paper 07/1 (Max-Planck-Institut für Gesellschaftsforschun January 2007) 8.

11 Polanyi (n 2) 147 and 156.

12 Ibid 146.

13 Kurtulus Gemici, 'Karl Polanyi and the Antinomies of Embeddedness' (2008) Socio-Economic Review 5-33, 7-10; Gareth Dale, 'Lineages of Embeddedness: On the Antecedents and Successors of a Polanyian Concept' (2011) 70(2) American Journal of Economics and Sociology 306-39, 323-25. 
between the embedded and disembedded economy; ${ }^{14}$ the argument that embeddedness does not go far enough in debunking standard economic models; $;^{15}$ and the concern about the way in which the language of embeddedness conjures up an image of separate spheres or systems: with 'markets' as asocial and separate from 'society' and with the two somehow communicating with each other, rather than being co-constitutive. ${ }^{16}$ A more helpful conceptualisation, referred to by many neo-Polanyians, is the idea of the 'always embedded market'. ${ }^{17}$ Barber says:

While the modern market system may appear to be more differentiated from other social system structures, somewhat more concretely separate, this image diverts attention from the basic fact of its multiple and complex interdependence with the rest of the social system. Calling the market 'disembedded' leads analytic attention away from just what this interdependence is. ${ }^{18}$

Without entirely abandoning the concept of embeddedness, Fred Block acknowledges that 'embeddedness is a relatively blunt instrument for analysing different types of market structures and arrangements' and suggests a focus on how markets are embedded and on degrees of embeddedness through the work of Zelizer and her concept of relational work. ${ }^{19}$ Other colleagues engaged in the economic sociology of law research agenda, however, use the concept of embeddedness as a preliminary starting point but soon depart from it in order to reframe the analysis of the relationship between 'the economic' and 'the social' through the lens of 'networks of community'. ${ }^{20}$

A third conceptualisation of embeddedness is that offered by Granovetter, who argues that orthodox neoclassical economic accounts provide an 'undersocialized' account of economic action, whilst sociology offers an 'oversocialized' conception; whereas in fact, he posits, most economic behaviour is closely embedded in networks of interpersonal relations. ${ }^{21}$ However, this interpretation of embeddedness, focusing on

14 Philippe Steiner, 'Who is Right about the Modern Economy: Polanyi, Zelizer, or Both?' (2009) 38 Theory and Society $97-110$.

15 Viviana A Zelizer, 'How I Became a Relational Economic Sociologist and What Does that Mean?' (2012) 40 Politics and Society 145-73, 148.

16 See the insightful deconstruction of the orthodox ways of configuring the relationship between the market and the social in Rittich, in this volume.

17 Fred Block, 'Karl Polanyi and the Writing of The Great Transformation' (2003) 32 Theory and Society 275-306, 276ff.

18 Bernard Barber, 'All Economies are "Embedded": The Career of a Concept, and Beyond' (1995) Social Research 387-414, 400.

19 Fred Block, 'Relational Work in Market Economies: An Introduction' (2012) 40 Politics and Society 135-44; Fred Block, 'Relational Work and the Law: Recapturing the Legal Realist Critique of Market Fundamentalism' (2013) 40(1) Journal of Law and Society 27-48.

20 Amanda Perry-Kessaris, 'Reading the Story of Law and Embeddedness through a Community Lens: A Polanyi-Meets-Cotterrell Economic Sociology of Law?' (2011) 62 Northern Ireland Legal Quarterly 401-13; Roger Cotterrell, 'Rethinking “Embeddedness”: Law, Economy, Community' (2013) 40(1) Journal of Law and Society 49-67.

21 Mark Granovetter, 'Economic Action and Social Structure: the Problem of Embeddedness' (1985) American Journal of Sociology 481-510. 
network structures, has been criticised for leaving intact the notion of an analytically autonomous economy criticized forcefully by Polanyi'. ${ }^{22}$

Nevertheless, what one can draw from these discussions is that the concept of embeddedness may retain a utility, provided we do not assume it predetermines or encodes the specific characteristics of modern capitalist economies, or the specificity of market organisation. Instead, what is useful is to see the concept as a means to understand the interdependence of market and society, to conceive of varieties of institutional regulation, with different market societies embedded in diverse configurations of ideas, rules and institutional structures. ${ }^{23}$ Of particular interest here is the extent to which the embedded liberal bargain can be struck at the supranational, rather than at the national, level and the potential for regional integration, the raison d'etre of which is market integration, to offer market governance which prevents the commodification of labour.

Ultimately, I still want to hold on to the idea of embeddedness, to the extent that it can be a useful way to understand how liberalised markets at EU level could be or have been contained within and by varieties of institutional structures at member state level, in particular labour, industrial relations and social welfare systems, so as to ensure that labour relations are not primarily determined by market forces. ${ }^{24}$ So, regional integration within the EU was premised on the existence of background rules at national level, of institutions of social citizenship, to ameliorate the effects of economic liberalisation. As Andrew Lang puts it:

In contrast with laissez-faire liberalism, the 'embedded liberalism' of the postwar period combined a commitment to free markets with a belief in the responsibility of governments to mitigate the social costs associated with free markets. ${ }^{25}$

Lang refers to the 'shared commitment to the political ideology of embedded liberalism' in the post-war era, which shaped, for instance, the General Agreement on Tariffs and Trade (GATT) regime. In other words, the dominant philosophy forming the backdrop to trade liberalisation and, eventually, to regional integration between industrialised nations was a recognition that governments should intervene to protect their populations 'from economic instability and insecurity' and promote their own versions of a welfare state. ${ }^{26}$ And what I would do is to extend the consensus that marked the international trade regime to the EU: European regional integration took place against an ideological backdrop favourable towards embedded liberalism. This is what Lang has to say about global trade, but there are clear resonances with trade at the regional level:

a trade regime in which the pursuit of free trade was defined and conducted in ways which minimized and avoided disruption to the kinds of interventions

22 Greta Krippner and Anthony Alvarez, 'Embeddedness and the Intellectual Projects of Economic Sociology' (2007) Annual Review of Sociology 105-28. Granovetter himself later observed 'I use the term "embeddedness" [in the 1985 article] in a narrower and somewhat different way than Polanyi meant it': Greta Krippner et al, 'Polanyi Symposium: A Conversation on Embeddedness' (2004) Socio-Economic Review 109-35, 113.

23 See Block (n 17) especially 299-300, where he examines the debt to Polanyi of the 'varieties of capitalism' literature. On varieties of capitalism, see J Rogers Hollingsworth and Robert Boyer (eds), Contemporary Capitalism: The Embeddedness of Institutions (Cambridge University Press 1997); Peter Hall and David Soskice (eds), Varieties of Capitalism: The Institutional Foundations of Comparative Advantage (Oxford University Press 2001).

24 Richard Hyman, 'The Europeanisation - or the Erosion - of Industrial Relations?' (2001) 32(4) Industrial Relations Journal 280-94, 281.

25 Lang (n 5) 29.

26 Ibid. 
associated with the welfare state. The regime pursued 'multilateral trade' rather than 'free trade' in some classical liberal sense: liberalization was pursued progressively, slowly and selectively; and the law was drafted and operationalized in ways which permitted - and indeed, presupposed - a high degree of government intervention. ${ }^{27}$

\section{Embedded liberalism and social regionalism: the EU example}

In his influential exploration of the international economic order through the lens of embeddedness, John Ruggie argues that the common tendency to view the post-war international economic regimes as essentially liberal regimes, premised on the need for (market) exchanges to be free, obscures the more complex reality, the compromise of 'embedded liberalism' that institutions were constructed to ensure that these exchanges should also be stable. The goal of the post-war international economic order was multilateralism in trade, but that goal was predicated on domestic interventionism. ${ }^{28}$ As Ruggie notes, there were differences among the industrialised countries in terms of 'the forms and depth' of state intervention to secure domestic stability (with, for instance, the US being less Keynesian than the UK) but not in the perceived legitimacy of the objective. $^{29}$

Such state intervention is necessitated in response to the opening of national borders brought about by trade liberalisation on the global plane, but also due to the process of regional economic integration. A key message of the report of the World Commission on the Social Dimension of Globalization, which was commissioned by the International Labour Organisation (ILO), related to the need for institutions to govern or 'tame' globalisation and to ensure a more equitable distribution of its benefits, since ' $[\mathrm{g}]$ lobal markets have grown rapidly without the parallel development of economic and social institutions necessary for their smooth and equitable functioning. ${ }^{30}$ This commission also highlighted the need for adjustment mechanisms, in both developed and developing countries. In the former, industrialised nations, there is the recognition that greater market access for developing country exports may impose high social costs, necessitating adjustment assistance to affected workers. ${ }^{31}$ In the latter, there is a need for donors and international and regional financial institutions to support nascent national social protection systems in order to ensure a fairer distribution of the gains from globalisation. ${ }^{32}$ 'Trade adjustment', as such policy responses are known, arises when an interventionist state is able to ensure that the losers from globalisation - or from regional market integration - are compensated, and may take the form of social transfers, of education policies, or of labour market policies in the effort to cushion the domestic effects of trade liberalisation and import competition. With regard to labour market

27 Lang (n 5) 40.

28 John Ruggie, 'International Regimes, Transactions, and Change: Embedded Liberalism in the Post-War Economic Order' (1982) 36 International Organization 379-415, 393.

29 Ibid 394.

30 World Commission on the Social Dimension of Globalization (WCSDG), A Fair Globalization: Creating Opportunities for All (ILO 2004) xi. This point is reiterated by Jenkins et al, who argue that: 'The current laissez faire globalization is unlikely to ensure a fair distribution of benefits across countries and there is a clear need to search for additional instruments of international and national policy to promote this': Hamish Jenkins, Eddy Lee and Gerry Rodgers, The Quest for a Fair Globalization Three Years On: Assessing the Impact of the World Commission on the Social Dimension of Globalization ILO Discussion Paper Series No 175 (ILO/International Institute for Labour Studies 2007) 20.

31 WCSDG (n 30) 82.

32 Ibid. 
policies, these may encompass measures insuring workers against adverse events - such as job security regulation to make it harder for employers to dismiss workers and unemployment benefits that grant workers income replacement during unemployment and those facilitating transition following trade reform.

Such efforts to ameliorate the effects of trade are a well-established feature of the economies of EU states, within their national borders. ${ }^{33}$ Individual states seek to protect vulnerable regions, sectors or workers from the effects of both intra-EU trade liberalisation and global trade. In addition to such ameliorative policies at national level, the constituent members of the EU confer on it both the economic capacity and legal competence (the power to act and to adopt binding norms) to provide for protective institutions at regional level through, for example, its social, regional and industrial policy.

What is apparent from the EU context is that regional trade integration places the social state under added pressure. To elaborate: in the creation of a 'common' or 'internal' market, there is arguably pressure on national economies to deregulate to remain competitive, since national capacity to regulate markets is severely reduced by the removal of barriers to trade, mobility of capital and fear of capital flight. Central to the EU internal market project from its origins in the European Economic Community Treaty of 1957 is the free movement of the 'factors of production' - goods, services, capital and labour - alongside competition law. Thus, labour is valued because it is marketable, a productive factor in trade. In deepening regional integration beyond that of a free trade area or a customs union, to allow for factor mobility, the European internal market project is necessarily implicated in the commodification of labour.

However, there was no question of the imposition of common social rights or labour law standards to compensate for any dislocation caused to labour by market integration. European integration was not designed or intended to replicate or replace institutions of social and industrial citizenship. The story that scholars of the EU, and in particular of its internal market, tell about EU integration is that it was premised on the understanding that the creation of a single market would not require harmonisation of labour standards, but instead rely on well-coordinated market-correcting institutions and the willingness to compensate for market failures existing mainly at national level. The original deal was this: differences such as those in labour costs or interest rates would tend to level up in a common market through the free circulation of the factors of production. The political and economic consensus, as evidenced in the intergovernmental Spaak Report ${ }^{34}$ preceding the 1957 Treaty of Rome, was that there was no need for labour standards at European level to balance trade liberalisation within the new economic community. Differences in levels of social protection or labour law or wage costs between states engaged in international trade did not, in themselves, pose a serious obstacle to competition or efficiency because these differences, it was believed, broadly reflected differences in productivity. Just as it was assumed that differences between states' labour law and industrial relations regimes would be absorbed in the process of creating a common market, such market creation was understood to be embedded within a post-war social settlement at the national level.

33 For more detailed discussion, see Diamond Ashiagbor, 'Unravelling the Embedded Liberal Bargain: Labour and Social Welfare Law in the Context of EU Market Integration' (2013) 19(3) European Law Journal 303-24.

34 Comité Intergouvernemental Créé par la Conférence de Messine, Rapport des Chefs de Délégation aux Minstres des Affaires Etrangères (the Spaak Report), summarised in English in Political and Economic Planning Planning No 405233 (1956). 
The key assertion here, to be contrasted with the experience of industrialising states, such as those in sub-Saharan Africa, is that the member states of this regional integration project have been the principal sources of their own trade adjustment. This is equally true of other industrialised countries such as the US, where market-correcting social and labour market institutions of the sort envisaged by the World Commission have long existed, in the form of state-mandated compensation to those who are perceived to have lost out from international trade liberalisation. ${ }^{35}$ What distinguishes the EU context from, say, the US is that this process of trade adjustment has, latterly, been sustained by support from the supranational level. The phrase 'European social model' is often used in discussions of European social and employment policy, as if it does not require definition. ${ }^{36}$ This rather nebulous concept should not be seen as implying uniformity in social systems across the EU, given the divergent welfare state models and diversity in the institutional form of labour market regulation. ${ }^{37}$ The European social model is better understood as a collective aspiration on the part of the EU and its member states towards sustainable economic growth, competitiveness and a 'dynamic knowledge-based economy', whilst also striving for social cohesion and social protection. ${ }^{38}$ This social model, if it is to have any real meaning, speaks to economic integration shored up by a social community. That social community is built on adjustment mechanisms at national level, as well as on a growing body of social law and policy at EU level. But, principally, the embedded liberal compromise in the EU context involved embedding the European internal market within national social policy. This was predicated on the ability of these industrialised nations to alleviate any adverse impact of market integration by embedding the market within national institutions of social citizenship: chiefly national systems of labour and social welfare law, public infrastructure and to fund social transfers and policy interventions. For a variety of reasons, however, this particular embedded liberal bargain has been unravelling prior to, but certainly accelerated by, the current global economic crisis. ${ }^{39}$ However, the key insight I wish to draw from the EU experience is the duality of embeddedness in the EU context.

35 'Those injured by trade competition should not be required to bear the full brunt of the impact. Rather, the burden of economic adjustment should be borne in part by the federal government . . . [T] here is an obligation to render assistance to those who suffer as a result of national trade policy': President John F Kennedy, 'Special Message to Congress on Foreign Trade Policy', 25 January 1962; quoted in Howard F Rosen, 'Strengthening Trade Adjustment Assistance' Policy Brief Number PB08-2 (Peterson Institute for International Economics 2008).

36 One example is the European Commission's communication on the social policy agenda which fails to provide a definition of the European social model despite spending over 30 pages examining how it will be 'modernised': European Commission, Communication from the Commission: Social Policy Agenda COM (2000) 379 final (European Commission 28 June 2000). However, a subsequent Commission Communication does state that 'Quality [in employment and social protection] is at the heart of the European social model': European Commission, Communication from the Commission: Employment and Social Policies: A Framework for Investing in Quality COM (2001) 313 final (European Commission 20 June 2001).

37 Richard Hyman, Britain and the European Social Model: Capitalism against Capitalism? IES Working Paper WP19 (Institute for Employment Studies 2009).

38 The Conclusions of the European Council meeting in Lisbon in 2000 committed the EU to a new strategic goal for the next decade: 'to become the most competitive and dynamic knowledge-based economy in the world capable of sustainable economic growth with more and better jobs and greater social cohesion': Presidency Conclusions, Lisbon European Council, 23 and 24 March 2000, BULL EU 3/2000, 7-17.

39 Elsewhere, I argue that, in addition to the challenges posed to the sustainability of European welfare states by the global economic crisis, the internal market jurisprudence of the Court of Justice, in judgments on the interaction between (EU) market freedoms and (national) labour law, which cast doubt on states' regulatory autonomy over labour or social welfare law, raise the issue of how effectively the 'embedded liberal bargain' can continue to operate: Ashiagbor (n 33). 
What Ruggie has referred to as the 'grand social bargain' 40 has, in the EU, had a distinctly regional dimension. This development was not anticipated within the economic orthodoxy at the founding of the European integration project. It thus seems apposite to claim, as Stefano Giubboni does, that the 'apparent flimsiness' of the social provisions of the original Treaty of Rome (minimal interventions, justified as essential to avoid distortions of competition) was deliberate. ${ }^{41}$

Despite these initial assumptions, that integration or trade liberalisation could proceed without the harmonisation of national systems of labour law and without the promotion of what might be understood as social citizenship at EU level, it is clear that the EU market integration project has evolved a significant social dimension, to complement that provided at the national level. This phenomenon, to deploy terminology adopted by Adelle Blackett, may usefully be described as social regionalism, the better to explore its wider applicability to other regions, in particular with regard to integration between developing states. ${ }^{42}$ Social regionalism in this sense can be said to entail a countermovement in the Polanyian sense - a regulatory response to protect vulnerable regions, sectors and workers from the impact of markets and trade liberalisation - but writ large, beyond the single nation state. This involves integration that is both solidaristic and redistributive: conceiving of the adjustment costs of trade as more than a matter for domestic policy and opposing the commodification of labour.

The approach, in the EU, emerging over several decades and accelerating following the Single European Act in 1986 and the Treaty on European Union in 1992, has been to build up the thin social policy provisions of the Treaty of Rome into what one could categorise as an attempt to re-embed the free market within the social, this time at EU level. Thus, the member states sanctioned redistribution on a large scale, in the form of 'non-social' adjustment mechanisms such as the Common Agricultural Policy, as well as smaller scale redistribution by means of the EU Structural and Cohesion Funds. ${ }^{43}$ We can also observe EU protection against global trade, for instance, by means of instruments such as the European Globalization Adjustment Fund that seeks to protect regions and sectors against global (in contrast to intra-EU) trade, by providing time-limited assistance to workers affected by redundancies caused by major structural changes in world trade patterns. ${ }^{44}$

The EU has evolved from an initial focus on social security and residence rights for Community workers moving from one member state to another; rights conferred by

40 John Ruggie, Taking Embedded Liberalism Global: The Corporate Connection Working Paper 2003/2 (Institute for International Law and Justice, New York University School of Law 2003).

41 Stefano Giubboni, Social Rights and Market Freedom in the European Constitution: A Labour Law Perspective (Cambridge University Press 2006).

42 Adelle Blackett, 'Toward Social Regionalism in the Americas' (2002) Comparative Labor Law and Policy Journal 901-65.

43 The collective title for the Regional Development Fund (ERDF), the Social Fund (ESF), the Fisheries Fund (Financial Instrument of Fisheries Guidance, or FIFG) and the Guidance and Guarantee Fund (European Agricultural Guidance and Guarantee Fund, EAGGF). See European Commission proposals for reforms to the structural and cohesion funds over the next programming period (2014-2020), the Union's future Cohesion Policy: European Commission proposals for new regulations (Brussels, 14 March 2012 $\operatorname{COM}(2011) 607$ final, and Brussels, 14 March $2012 \operatorname{COM}(2011) 615$ final).

44 The European Globalization Adjustment Fund is not dissimilar to the US Trade Adjustment Assistance programme in that it represents targeted assistance of short duration, specifically for those who have lost jobs as result of international trade: Regulation No 1927/2006 of the European Parliament and of the Council of 20 December 2006 on establishing the European Globalisation Adjustment Fund, L 40630 December 2006; corrected by Corrigendum to Regulation No 1927/2006, OJL 48/82, 22 February 2008. 
virtue of the contribution these 'factors of production' were making to market integration. Increasingly, member states have conferred competence on the EU to develop a free-standing body of European social law and policy, justified not solely on the basis of the economic value of transnational labour standards within the context of market integration, but also on the basis of a wider concern to respect fundamental rights and construct a sense of identification with the EU project through citizenship rights.

Indeed, it may be that the European project has been instrumental in rescuing the social state. ${ }^{45}$ Writing recently in the New Left Review, Alain Supiot describes the (social) state as merely a mode for the realisation of the objective of social solidarity. He talks of conceiving 'an international legal order that will prohibit the use of open borders to escape the duties of solidarity inherent in the recognition of economic and social rights'. Ultimately, he asks: 'Is the social state still in a position to undertake this mastery, or is it rather condemned to make way for other institutional constructs?' 46 This, to be fair, is a question that is only really relevant in relation to industrialised countries, or perhaps the OECD world. It's not meaningful to ask if industrialising states are 'still in a position' to serve this protective function. Nancy Fraser, writing in an earlier issue of the New Left Review, reaches a similar conclusion, though she argues more bluntly that 'the project of social protection can no longer be envisioned in the national frame'. She also acknowledges that postcolonial states never enjoyed protective capacities equal to those of 'the core', thanks to 'long histories of colonial subjection, as well as to the continuation, after independence, of imperialist predation by other means'. ${ }^{47}$

If not the state, what of the region? I am interested in exploring the potential of regional integration as a response to the open borders of globalisation. ${ }^{48}$ What is ironic, as can be seen in the case of the EU, is that regional integration, with its opening of national borders and the removal of barriers to trade between states, can be both a cause of, or an exacerbating factor in, undermining the autonomy of the state to operate systems of social protection within a territorially bounded labour market. But, equally, regional integration offers a potential solution or potential counter-weight: after its initial 'hands off' approach towards social policy, on the basis that the creation of a single market for the European Economic Community would not require harmonisation of labour standards or national systems of labour law, the EU evolved a supranational social dimension both to protect vulnerable regions, sectors and workers from the effects of intra-EU trade liberalisation and to offer protection against global trade. Admittedly, as far as the EU is concerned, that social dimension has to a great extent been unravelling in recent years; or rather, the economic constitution that was always the core of the EU project is now serving to undermine the capacity of member states to maintain certain social models, especially corporatist forms, at national level. But the point I want to make about the value of the region is that, in the past and in the case of the EU, it was able to serve as a complement and even a bolster to the social state. The EU sought to shore up working and living standards in the face of economic liberalisation, but did so principally by supporting the member states in so doing. The incremental development of a framework of basic minimum standards at EU level came out of the recognition that the

45 I owe this phraseology to Alan Milward, The European Rescue of the Nation-State (Routledge 1994).

46 Alain Supiot, 'Grandeur and Misery of the Social State' (2013) 82(July/August) New Left Review 99-113, 110.

47 Nancy Fraser, 'A Triple Movement? Parsing the Politics of Crisis after Polanyi' (2013) 81(May/June) New Left Review 119-32, 126.

48 Luk Van Langenhove and Tiziana Scaramagli, 'Regional Integration as a Response to Globalization' in Jorge Heine and Ramesh Thakur (eds), The Dark Side of Globalization (UNU Press 2011). 
very process of economic liberalisation was placing demands on the ability of states to maintain living and working standards. Such intervention was justified by a complex set of rationales, including the need to protect against destructive downwards competition.

\section{Social regionalism and the Global South}

The final part of this paper will outline a research agenda to consider ways in which this work on embeddedness and social regionalism in the Global North may have an application in the Global South. Embedded liberalism of the type discussed earlier - Ruggie's 'grand social bargain' whereby markets are shored up by a social community built on adjustment mechanisms at national level - seems relevant predominantly for industrialised economies. In the case of the US, federal government is deemed an appropriate bearer of the burden of economic adjustment. Similarly, the initial logic underpinning European economic integration was that national institutions of social citizenship would absorb the economic insecurity arising from liberalising previously closed national markets. The EU has grown from a membership of six relatively homogeneous states to a group of 28 . In particular, expansion to the east in 2004, 2007 and 2013 has brought with it greater heterogeneity of national social welfare systems, raising the question of how successfully EU states are able to resource domestic institutions to cushion the negative social consequences of market integration and restructuring. ${ }^{49}$ However, whilst social expenditure in the newer member states varies widely, the proportion of gross domestic product (GDP) devoted to social expenditure, allowing for economic development and income level, compares favourably to that in the old member states. 50

However, it is highly problematic to expect individual states within, for example, subSaharan Africa to be the only, or main source of their own adjustment. ${ }^{51}$ Unsurprisingly, the contrast between the EU and Africa is sizeable, with average GDP per capita in 2010 measuring $€ 24,400$ for Europe and $€ 1258$ for Africa. ${ }^{52}$ Clearly, less industrialised nations have never enjoyed adjustment mechanisms of the sort that have existed in industrialised states. They do not have the 'privilege of cushioning the adverse domestic effects of market exposure in the first place [since the] majority lack the resources, institutional capacity [and] international support'. 53

49 Although there is a trend towards increased convergence of European economies as measured by their gross domestic product (GDP) per capita, it is certainly the case that the member states acceding to EU membership in the post-2004 era still have a significantly lower GDP than the average for the EU as a whole: Lars Svennebye, 'GDP per Capita, Consumption per Capita and Comparative Price Levels in Europe', in Eurostat (the statistical office of the EU), Statistics in Focus: Economy and Finance 112/2008 (Eurostat 2008). In 2011, Bulgaria's GDP per inhabitant was just 46 per cent of the EU average, Romania's 49 per cent, and Latvia's 58 per cent. In contrast, Luxembourg was at 271 per cent of the EU average and the Netherlands at 131 per cent.

50 Gábor Juhász, 'Exporting or Pulling Down? The European Social Model and Eastern Enlargement of the EU' (2006) European Journal of Social Quality 82; Maarten Keune, 'The European Social Model and Enlargement' in Amparo Serrano Pascual and Maria Jepsen (eds), Unwrapping The European Social Model (Policy Press 2006).

51 Blackett (n 4) 24.

52 Eurostat and AU Commission Statistics Division, The European Union and the African Union: A Statistical Portrait (European Commission 2012). More remarkable, however, are the striking disparities between African states, in contrast to the smaller deviation in the EU. The gap between those states in Africa with the lowest and the highest GDP (Burundi with GDP of $€ 124$; the DRC with GDP of $€ 151$; Equatorial Guinea with GDP of $€ 13,331)$ is considerably greater than with regard to their equivalents in the EU (Bulgaria with GDP per capita of $€ 4800$ euro; Luxembourg, with GDP per capita of $€ 79,500)$.

53 Ruggie 2001 (n 40) 2. 
Of the alternative sources of adjustment beyond the nation state - international, regional or bilateral action - there have been attempts at institutions on the international plane, such as the United Nations Conference on Trade and Development (UNCTAD), which from the 1960s aimed at fostering development and channelling wealth to the South. However, the marginalisation of this institution meant that it never became a serious challenger to the liberalisation agenda of GATT and the World Trade Organization. ${ }^{54} \mathrm{My}$ focus is therefore on the regional, asking whether regional integration between developing countries can assist individual states in this process of strengthening society to protect their populations from economic instability. There is, after all, a common rationality underpinning regional integration in both Africa and in Europe: first, to enhance political unity at the pan-African or European level; second, to foster economic growth and development. ${ }^{55}$ Could the phenomenon of social regionalism, wherein there is an attempt to spread the adjustment costs of global trade across interconnected states, by means of regional integration which is both solidaristic and redistributive, similarly have resonance beyond the EU?

In answering this, I want to focus on two main factors that are likely to militate against the development of the sort of social regionalism witnessed within the EU: the broader neoliberal turn, combined with the weaker (social) state within the individual member states of developing-country trading blocs. In being attentive to the distinctive circumstances that made possible the varieties of trade adjustment or embedded liberalism in the Global North, there are nevertheless important insights to be gleaned from the experience of social regionalism in the EU. The EU has shown the possibilities of regionalisation with a strong social dimension. Undoubtedly, differences in economic development militate against any simple transposition of the EU's social model, premised as it is on the institutions of social citizenship within its member states. It is, however, valuable to identify how regional integration can complement states' efforts to protect the 'social' from global market forces - and to interrogate which elements of social regionalism might be applicable to other regions.

Regional integration and cooperation have the potential to contribute to a more equitable pattern of globalisation, provided it has a strong social dimension, ${ }^{56}$ for instance, through enabling regional social redistribution mechanisms, regional social and labour regulation and regional sectoral social policies. Further, social regionalism can be a constructive challenge to neoliberal visions of liberalisation. ${ }^{57}$ Bob Deacon has categorised different facets of social policy as involving social redistribution, social regulation and the promulgation of social rights. ${ }^{58}$ In the EU case, one can observe all three, in particular intra-region redistribution, through mechanisms such as the European Structural Funds, or measures to promote economic development in low income members on accession. Whilst by necessity requiring different mechanisms for

54 Jens Steffek, 'Who Compensates the Losers? Embedded Liberalism, Inequality and the Limits of Global Governance' unpublished paper on file with the author.

55 UNCTAD, Economic Development in Africa Report: Strengthening Regional Economic Integration for Africa's Development (United Nations 2009).

56 WCSDG (n 30) 71; Luk Van Langenhove and Maria Cristina Macovei, 'Regional Formations and Global Governance' in Bob Deacon, Maria Cristina Macovei, Luk Van Langenhove and Nicola Yeates (eds), WorldRegional Social Policy and Global Governance (Routledge 2009) 25; Stephen Kingah, Regionalising Global Social Policy in Times of Economic Crisis Working Paper W-2013/7 (UNU-CRIS 2013).

57 Blackett (n 42) 904.

58 Bob Deacon, Global Social Policy and Governance (Sage 2007); Bob Deacon, 'Regional Social Policies in Africa: Declarations Abound' in Deacon et al (n 56) 186. 
ameliorating the disruptive force of market-making and liberalisation of existing markets, what is the scope for regional social policy across the continent of Africa?

In particular, regionalisation initiatives in sub-Saharan Africa, such as the African Union, and efforts towards sub-regional integration, such as the Southern African Development Community (SADC) and the Economic Community of West African States, face a number of obstacles that prevent both the deepening of integration and the deepening of the social dimension of such integration. What is promising, however, is that these are models of economic integration that go beyond market access and trade liberalisation to claim a broader human rights and social policy mandate, even if this dimension is not fully developed. ${ }^{59}$

\section{INTERNAL CONSTRAINTS}

There are a number of potential internal obstacles, most notably relating to the nature of the 'state', which is engaged in regional integration, and to the institutional design of regional governance. ${ }^{60}$ An important background concern is the absence of structural stability, namely, peace and security. To take the example of SADC, it has a membership of 15 states, including Botswana, South Africa, Mozambique, the Democratic Republic of the Congo (DRC) and Zimbabwe, ${ }^{61}$ but is, however, relatively weak in institutional terms, a weakness which is further exacerbated by the wider politics of the region - for example, political instability in the DRC and Zimbabwe. ${ }^{62}$ More generally, many states in the African context are fragile and their fiscal bases small. ${ }^{63}$ There are, in my view, two closely interrelated inhibiting factors, related to the process of state formation and approaches to regional governance. First, is the reluctance of developing and/or newly postcolonial states to constrain their sovereignty through supranational (as opposed to intergovernmental) decision-making. Having acquired political autonomy and statehood relatively recently and facing constraints on policy action from outside their borders, individual states are reluctant to cede norm-making power to a central or supranational body. Integration arrangements within regional economic communities across Africa are thus normatively loose, tending towards what one might call decisional intergovernmentalism. ${ }^{64}$ It will be important to explore the institutional design of regional economic integration within Africa: in particular, whether a better view of the 'looseness' of these institutional arrangements is that they are designed to be flexible regimes of cooperation, precisely in order to better suit the multiple policy objectives of the African context and to allow for greater state sovereignty. ${ }^{65}$ Second, the multiplicity of regional economic communities, and their overlapping 'mandates, objectives,

59 Zolomphi Nkowani, 'When Elephants Dance, The SADC Charter of Fundamental Social Rights: A Beacon of Hope or Confusion Compounded?' (2007) 33(1) Commonwealth Law Bulletin 41-54.

60 Rodrigo Tavares and Vanessa Tang, 'Regional Economic Integration in Africa: Impediments to Progress?' (2011) 18(2) South African Journal of International Affairs 217-33.

61 The full list of members is: Angola, Botswana, the DRC, Lesotho, Madagascar, Malawi, Mauritius, Mozambique, Namibia, Seychelles, South Africa, Kingdom of Swaziland, Tanzania, Zambia, Zimbabwe.

62 Bob Deacon, 'The Social Dimension of Regionalism: A Constructive Alternative to Neo-Liberal Globalisation?' Occasional Paper No 8/2001 (Globalism and Social Policy Programme 2001) 17.

63 Peter Draper, 'Breaking Free from Europe: Why Africa Needs Another Model of Regional Integration' in Lorenzo Fioramonti (ed), Regionalism in a Changing World: Comparative Perspectives in the New Global Order (Routledge 2013) 77.

64 For discussion of a contrasting approach, the slow turn to a form of 'decisional supranationalism' within the EU, see Joseph Weiler, 'The Transformation of Europe' (2001) Yale Law Journal 2403-83.

65 James Thuo Gathii, ‘African Regional Trade Agreements as Flexible Legal Regimes' (2010) 35 North Carolina Journal of International Law and Commercial Regulation 571-668. 
protocols, and functions', 66 further inhibit the development of spheres of policy influence at the regional level that are able to direct or influence national policy. The multiple overlapping memberships complicate regional governance, ${ }^{67}$ one outcome of which is weak regional support for emergent national institutions of social citizenship, in part due to the lack of institutional arrangements to attract either international or intraregional transfers. ${ }^{68}$

\section{EXTERNAL CONSTRAINTS}

Externally, these states and regions face social dislocations caused by global or European trade policies, as well as constraints on their sovereignty resulting from the institutional design of the global trade regime. Industrialising states in sub-Saharan Africa, in many cases, lack the requisite political autonomy, even in the aftermath of decolonisation. Polanyi observed:

But if the organized states of Europe could protect themselves against the backwash of international free trade, the politically unorganized colonial peoples could not. The revolt against imperialism was mainly an attempt on the part of [colonial] peoples to achieve the political status necessary to shelter themselves from the social dislocations caused by European trade policies. The protection that the [Europeans] could easily secure for [themselves], through the sovereign status of [their] communities was out of reach of the [the colonized] as long as [they] lacked the prerequisite, political government. ${ }^{69}$

As Blackett notes, for many of the industrialised nation states of Europe entering the GATT at the end of the Second World War, colonial preferences enabled them to continue a pattern of exchange (or unidirectional trade) between the colonies and the metropolitan territories. ${ }^{70}$ With regard to the impact externally of the EU's economic model, this in particular potentially destabilises the development of redistributive social institutions, or region-specific adjustment mechanisms within those industrialising states with which the EU trades. For instance, a not insignificant effect of reciprocal trade liberalisation between the EU and its developing-country trading partners is to impede intra-regional transfers, as tariff revenues within developing countries diminish due to reciprocal trade liberalisation with industrialised states. ${ }^{71}$ This tension between regional economic integration and external (bilateral) trade agreements may serve to undermine

66 United Nations Economic Commission for Africa and African Union, Assessing Regional Integration in Africa II, Rationalizing Regional Economic Communities (UNECA 2006) 110.

67 UNU-CRIS, Deepening the Social Dimensions of Regional Integration: An Overview of Recent Trends and Future Challenges in Light of the Recommendations of the Report of the World Commission on the Social Dimension of Globalisation Discussion Paper Series No 188 (International Institute for Labour Studies/ILO 2008); Malte Brosig, 'Overlap and Interplay between International Organisations: Theories and Approaches' (2011) 18(2) South African Journal of International Affairs 147-67.

68 Nicola Yeates and Bob Deacon, 'Globalization, Regional Integration and Social Policy' in Deacon et al (n 56) 29.

69 Polanyi (n 2) 192.

70 Blackett (n 4) 1.

71 Deacon (n 62). See Council Decision 2004/441/EC of 26 April 2004 concerning the conclusion of the Trade, Development and Cooperation Agreement between the European Community and its Member States, on the one part, and the Republic of South Africa, on the other part, OJL 127, 109, 29 April 2004. 
regional solidarity, as can be observed in the opposition to EU-initiated Economic Partnership Agreements. ${ }^{72}$

Edward Webster and Robert Lambert, in a paper entitled 'Markets against Society: Labor's Predicament in the Second Great Transformation', ${ }^{73}$ argue that the Polanyian trajectory, the creation of a link between wage labour and social citizenship at the core of the welfare state, never occurred in the South, as 'their own democratic transition occurred at the very moment of the Second Great Transformation'. As Fraser reminds us, the absence, in postcolonial states, of the protective capacities witnessed within the North was exacerbated by neoliberal policies of structural adjustment. ${ }^{74}$ Webster and Lambert draw a Polanyian scenario as follows:

[n the North] The sphere of the public and the social, which had been established by the counter-movement in response to the domination of the market during the First Great Transformation, is being rolled back by the forces of neoliberal globalization unleashed in the Second Great Transformation.

... in contrast to the North, countries of the South such as South Africa have never experienced the successful construction of a welfare state through the counter-movement of society in response to the market forces of the First Great Transformation. The task facing society is not the defense or strengthening of society and the public domain, but rather to form a countermovement for the construction of an integrated society and of a public domain against the market for the first time - and in the face of the even more powerful market forces of the Second Great Transformation. ${ }^{75}$

A related constraint for regional integration projects in the Global South concerns their response to the institutional design of the global trade regime. Whereas, it could be argued that the aims of the original wave of regional integration projects of the $1950 \mathrm{~s}$ and 1960s had at their core the evolution of the postcolonial developmental state, concerned with reducing North-South dependence, the wave of regionalism since the 1990s has been in contrast more focused on the objective of integrating these developing economies more closely into global markets. ${ }^{76}$ It will be interesting to trace the impact of the shift away from an earlier form of integration based on protectionism towards the neoliberal trade liberalisation paradigm. Accordingly, Olivet and Brennan talk about the importance of 'reclaim[ing] regional integration from the neo-liberal trend'. ${ }^{77}$

It would seem that regional integration between developing countries is in fact a greater catalyst for the turn to neoliberalism than occurred within earlier instances of regional integration between industrialised countries. We have seen an increased resort to bilateral and regional trade agreements that James Thuo Gathii describes as a primary means through which to realise greater investor protections, commodification of social

72 Matthias Busse and Harald Großmann, Assessing the Impact of ACP/EU Economic Partnership Agreement on West African Countries HWWA-World Economy, HWWA Discussion Paper (Hamburg Institute of International Economics August 2004); Christopher Stevens, 'The EU, Africa and Economic Partnership Agreements: Unintended Consequences of Policy Leverage’ (2006) 44(3) Journal of Modern African Studies 441-58.

73 Edward Webster and Robert Lambert, 'Markets against Society: Labor's Predicament in the Second Great Transformation' in Ann Denis and Devorah Kalekin-Fishman (eds), The ISA Handbook in Contemporary Sociology: Conflict, Competition, Cooperation (Sage 2009).

74 Fraser (n 47).

75 Webster and Lambert (n 73) 268 (emphasis in original).

76 Cecilia Olivet and Brid Brennan, 'Regional Social Policy from Below: Reclaiming Regional Integration Social Movements and Civil Society Organizations as Key Protagonists’ in Deacon et al (n 56) 67.

77 Ibid 67. 
services, guaranteed rights of investor access to investment opportunities, privatisation of public service goods and, generally, the diminution of sovereign control. ${ }^{78}$

But whilst state sovereignty is being weakened, it is not - as in the case of the EU being transferred up to the regional plane. For Gathii, the spaghetti bowl of overlapping regional economic communities is no bad thing if it reflects, as he would argue, a desire on the part of these nation states to retain national sovereignty rather than be enveloped within an inexorable move towards closer, tighter, more supranational forms of integration. His argument is that it suits postcolonial sub-Saharan African states to enter into these looser regional arrangements and not to aspire to the form of economic integration, with binding centrally determined norms that have characterised European regional integration. But my concern is that this makes it even more difficult to resist, ameliorate or counter neoliberal trade.

\section{Conclusions: new regionalism and counter-movements in the Global South}

Writing in 1945, in a paper entitled 'Universal Capitalism or Regional Planning?', Polanyi cautioned that 'regionalism is not a panacea'. ${ }^{79}$ Whilst regional cooperation has the potential to contribute to a more equitable pattern of globalisation, nonetheless, the questions for future research are in what form of regionalism will the postcolonial state be located and in what institutional structures are these nascent forms of market integration to be embedded?

Welfare states were one example of the self-defence mechanism against the growth of the market, the self-protection of society that we can observe in industrialised states. ${ }^{80}$ But what form do the counter-movements in industrialising states take? As Ronaldo, Munck points out, the postcolonial developmental state, based on state-led industrialisation behind protectionist barriers, was another example of societal selfprotection. Whilst not as wide-ranging as the strong social protection mechanisms of industrialised economies, the developmental state also introduced an element of social security. However, Munck also notes:

Since the neoliberal offensive (or counter-counter-movement in Polanyi's terms) of the 1980s and 1990s both the above elements have been severely curtailed or reversed. The development state has been forced to 'open up' the developing economy to powerful transnational capitalist interests. ${ }^{81}$

Challenges posed to the sustainability of European welfare states have led to a retrenchment of these social protective elements, an unravelling of that embedded liberal bargain. ${ }^{82}$ In industrialising states, in contrast, it is necessary to explore political and economic constraints on regional integration that frustrate what could well be a genuine counter-movement to soften the growth of the market. Undoubtedly, the active role of the developmental state in stimulating and directing economic growth has been challenged by the neoliberal turn in the international economic order and the dominance of the Washington Consensus. However, some have identified a resurgence of new ways

78 James Thuo Gathii, 'The Neo-Liberal Turn in Regional Trade Agreements' (2011) Washington Law Review 421-74.

79 Karl Polanyi, 'Universal Capitalism or Regional Planning?' (1945) 10(3) London Quarterly of World Affairs 86-91, 89.

80 Ronaldo Munck, 'Globalization and Contestation: The New Great Counter-Movement' (2006) 3(2) Globalizations 175-86, 181.

81 Ibid.

82 Ashiagbor (n 33); Barbara Kees van Kersbergen Vis and Tom Hylands, 'To What Extent Did the Financial Crisis Intensify the Pressure to Reform the Welfare State?' (2011) Social Policy and Administration 338-53. 
in which developing nations (specifically, in Latin America) are exploring how they can and should promote both growth and equity. ${ }^{83}$ Whilst acknowledging that a Polanyian counter-movement need not necessarily take the form of a social movement, it is clear that a societal response at the regional level may well be muted if priority is given to market governance in order to secure entry into the global trade regime. How then, in the newer waves of regional economic integration in the Global South, can the shift away from the explicitly protectionist developmental nation state nevertheless create space for a regulatory rejoinder to free markets?

83 David M Trubek, 'Developmental States and the Legal Order: Towards a New Political Economy of Development and Law' Working Paper (Law and the New Developmental State (LANDS) 2010) $<$ www.law.wisc.edu/gls/lands.html>. 
